УДК $811.111 ’ 367: 821.111$

DOI https://doi.org/10.26661/2414-9594-2021-1-5

\title{
ПАРЦЕЛЯЦІЯ ЯК ОДИН 3 ЕЛЕМЕНТІВ ЕКСПРЕСИВНОСТІ В СИСТЕМІ ІДІОСТИЛЮ РЕЯ БРЕДБЕРІ (НА МАТЕРІАЛІ ТВОРУ «451 ГРАДУС ЗА ФАРЕНГЕЙТОМ»)
}

\author{
Боговик О. А. \\ кандидат філологічних наук, \\ старший викладач кафедри філологї̈ та перекладу \\ Дніпровський національний університет залізничного транспорту \\ імені академіка Всеволода Лазаряна \\ вул. Лазаряна, 2, Дніпро, Украӥна \\ orcid.org/0000-0003-4315-2154 \\ oksana.a.bogovik@gmail.com
}

\begin{abstract}
Ключові слова: паричеляція, стилістичні засоби, експресивний синтаксис, синтаксична конструкиія, художній текст, функиія, Рей Бредбері.
\end{abstract}

У статті розглянуто теоретичні аспекти явища парцеляції як синтаксичного прийому організації тексту. Аналізуються точки зору вчених-лінгвістів на особливості функціонування у мові парцельованих конструкцій. Акцентовано увагу на тому, що парцеляція як багатоаспектне явище вивчається у лексико-семантичній, граматичній, структурній, стилістичній, текстовій та інших площинах. У наукових лінгвістичних розвідках парцеляція характеризується як явище експресивного синтаксису та знаходить вираження у різних стилях мови. Однією 3 основних характеристик художнього дискурсу визначають його здатність формувати емоційно-цілісне сприйняття літературного матеріалу.

Аналіз прозового роману-антиутопії, який написано у жанрі наукової фантастики, американського письменника Рея Бредбері «451 градус за Фаренгейтом» засвідчує, що парцеляція $\epsilon$ одним 3 елементів індивідуально-авторської манери письменника. Причина вживання парцельованих конструкцій зумовлена жанром твору. Так, у художньому дискурсі зазвичай автор не лише описує факти та події, які відбуваються у житті його героїв, але й дає емоційну оцінку того, про що повідомляється. Звернено увагу на різні види парцельованих конструкцій та детально проаналізовано ті, які використано як інструмент досягнення експресивності. Окреслено основні функції, які відіграє парцеляція в ідіостилі письменника, такі як емоційна, описова, логічна, смислова та функція конкретизації сенсу повідомлюваного. Вживання парцельованих конструкцій у тексті полегшує сприймання тексту читачем, акцентує увагу на найголовнішому, допомагає відобразити настрій героїв твору. 3’ясовано, що у романі Рея Бредбері «451 градус за Фаренгейтом» парцеляція $\epsilon$ функціонально навантаженим засобом експресивного синтаксису, що відзначається виразністю, структурною варіативністю, яскравістю та переконливістю створюваних письменником образів. Парцеляція посилює зміст приєднуваного компонента, що допомагає уточнити та конкретизувати тему. Встановлено, що проаналізована конструкція розчленованого син 


\title{
SENTENCE FRAGMENTATION AS AN ELEMENT OF EXPRESSIVENESS IN THE SYSTEM OF RAY BRADBURY'S INDIVIDUAL STYLE (BASED ON THE NOVEL "FAHRENHEIT 451")
}

\author{
Bohovyk O. A. \\ PhD in Philology, \\ Senior Lecturer at Philology and Translation Department \\ Dnipro National University of Railway Transport named after Academician Vsevolod Lazarian \\ Lazarian str., 2, Dnipro, Ukraine \\ orcid.org/0000-0003-4315-2154 \\ oksana.a.bogovik@gmail.com
}

Key words: sentence fragmentation, syntactic construction, expressive syntax, syntactic construction, fiction, function, Ray Bradbury.

\begin{abstract}
The article deals with theoretical aspects of the sentence fragmentation as a syntactic text organization. Standpoints of linguists on the peculiarities of language sentence fragment patterns have been analyzed. Emphasis is placed on the fact that the abovementioned stylistic device as a multidimensional phenomenon is studied in lexical-semantic, grammatical, structural, stylistic, textual, and other areas. In linguistic researches, the sentence fragment is characterized as an expressive syntax phenomenon that functions actively in different language styles.

Analysis of Ray Bradbury's dystopian science fiction novel "Fahrenheit 451" testifies that the sentence fragmentation is one of the features of the individual author's writing. The reason for the use of such constructions is determined by the genre of the work: in a fiction discourse, the author not only describes the characters' reactions to facts or events but also gives an emotional assessment of what reported is.

Attention is paid to different types of fragmentary sentences and detailed analysis of those which are used as a tool for expressiveness is given. The main functions of the sentence fragmentation in the author's individual style are determined in this article, such as emotive, descriptive, logical, and sense-making, and the function of concretization of the plot. The use of such constructions in the novel makes readers percept the text easier, emphasizes the most important information, and helps to reflect the characters' mood. It has been proved that in Ray Bradbury's novel "Fahrenheit 451" the sentence fragmentation is a functionally loaded means of expressive syntax marked by expressiveness, structural variability, brightness, and persuasiveness of images created by the writer. Sentence fragmentation increases the content of the attached component and helps to clarify and specify the topic. It is established that the analyzed stylistic device is one of the features of Ray Bradbury's individual style.
\end{abstract}

Постановка проблеми. Вживання синтаксичних мовних засобів авторами творів різних стилів зорієнтовано на незвичність слововживання, посилення емоційності та образності повідомленої або висловленої інформації, а також слугують відображенням індивідуального стилю письменника. Серед синтаксичних явищ, які сьогодні існують у мовах, парцеляція відзначається оригінальністю форми, що простежується навмисним розподілом слів, які зв'язані за змістом та граматично і виражають закінчену думку. Таке розчленування приводить до модифікаційної зміни структури простого або складного речення, що «є суттю парцеляції як особливого явища комунікативного аспекту, яке зв’я- зане 3 актуальним членуванням $\mathrm{i}$ - ширше - взагалі 3 комунікативним аспектом мовлення» [1, с. 162]. Досліджувана стилістична фігура на письмі розрізняється за допомогою розділових знаків, таких як крапка, три крапки, знак оклику чи знак питання, які ставляться після семантично пов'язаних членів речення, завдяки чому синтаксична конструкція стає формально незалежною. У парцельованих конструкціях найуживаніший розділовий знак, який вказує на синтаксичний розподіл, - це крапка. Саме пунктуація дає змогу інтонувати текст під час його зорового сприйняття.

Вирішальну роль в атракції читачів до художнього твору відіграють два чинники, такі як 
інтерпретація тексту та використання автором мовних засобів. Парцеляція належить до прийомів, які завдяки конструкції сприймаються як порушення мовних норм. Проте більшість письменників, вживаючи ті чи інші стилістичні засоби, покладаються на інтуїцію або визначають їх як можливі варіанти, враховуючи частотність уживання у творах різних жанрів [23].

Парцеляція як прийом стилістичного синтаксису привертав увагу багатьох дослідників, а також отримував різні варіанти найменування. Першим звернув увагу на дослідження мовленнєвого членування речення чеський мовознавець В. Матезіус, який розмежував конструктивний та функціональний аспекти речення. Швейцарський науковець Ш. Баллі назвав відокремлення частини речення дислокацією, російські лінгвісти О. Пєшковький та О. Шахматов вважали таке від'єднання неповними реченнями, О. Реферовська та Н. Шигаревська вживали термін «сегментація», а лінгвіст О. Андрієвська - термін «сепаратизація», мовознавці В. Гак і О. Реферовська описали зазначений прийом як приєднувальні конструкції, науковці Є. Ризель та Є. Шендельс використовували найменування «ізоляція», а мовознавиця Л. Чахоян, врахувавши характерну структурну особливість феномена, описала його як комунікативні структури 3 додатковою рематизацією семантико-синтаксичних конструкцій. Вивчаючи парцеляцію, дослідники Л. Щерба i В. Виноградов використовували термін «приєднання». Наприкінці XX століття науковці Л. Суровенкова та Е. Вильчицька довели, що парцеляція та приєднання - це різні синтаксичні явища, а сам термін у його сучасному розумінні вперше було використано лінгвістом О. Єфрємовим [3]. В англійському мовознавстві парцеляція потрактовується як ненормативне явище, яке отримало назву minor sentence [19], fragmentary sentence [21, с. 67] або sentence fragmentation [20].

Парцеляція досліджувалась як «представленість речення у вигляді двох або декількох фраз iз експресивною метою» [9, с. 23-29], «спосіб мовного представлення єдиної синтаксичної структури - речення 3 кількома комунікативно-самостійними одиницями - фразами» [16], або це слова, фрази чи речення, які не можуть бути класифіковані як синтаксично повні речення, які графічно нагадують речення [19], де сенс парцельованої конструкції «полягає в тому, щоб надати мовленню динаміки, щоб спеціально порушити звичні синтагматичні моделі задля емоційного підкреслення, емфатичного виділення тих чи інших слів і словосполучень» [14, с. 174]. К. Уейлс резюмує, що такі конструкції на тлі унормованих уживань решти тексту призводять до їх «помітності» [24, с. 157]. Надаючи різні дефініції, науковці одностайні у тлумаченні явища як синтаксичного процесу, «сутність якого полягає у розчленуванні на самостійні одиниці єдиного синтаксичного цілого; парцельована конструкція складається 3 парцелята та базової частини» [13, с. 118-129], де парцелят розширює інформаційну насиченість, інтенсифікує смислове значення неядерних компонентів речення, надає їм виразності [12, с. 70]. Серед дослідників переважає думка про те, що «винесення повторюваної лексичної одиниці у парцеляті підсилює його емоційну й логіко-емоційну наповненість, збільшуючи смислову виразність речення» [15, с. 121-122], тобто характерне для художнього дискурсу вживання експресивних синтаксичних конструкцій зумовлює актуальність дослідження вживання парцеляції як засобу експресивного синтаксису.

Незважаючи на значну кількість наукових розвідок, які порушують питання функціонування парцеляції в усному мовленні та на письмі, залишається перспективним дослідження зазначеного мовного явища на матеріалах текстів різних жанрів та використання його письменниками як синтаксичного засобу вираження експресивності.

Мета статті полягає у дослідженні вживання парцелятів як синтаксичних експресем 3 урахуванням їхньої структури, семантики та текстоутворювальних можливостей на матеріалі роману письменника Р. Бредбері «451 градус за Фаренгейтом», що досі не ставало предметом детального вивчення лінгвістів.

Виклад основного матеріалу дослідження. Семантика художнього тексту складає концептуальну базу для висвітлення емотивного профілю тексту $[17$, с. 10]. Емоції допомагають відобразити об'єкти реальної картини світу та слугують формуванню мовної картини світу. Людина, емоційна за своєю природою, виступає активатором такого процесу, мова - засобом, а емоції - формою відображення об'єктивної дійсності [2, с. 196]. Описуючи ту чи іншу емотивну ситуацію, автор свідомо моделює емоційний відгук адресата, користуючись власним сприйняттям дійсності [17, с. 2].

Роман Рея Бредбері «451 градус за Фаренгейтом» вирізняється стилем оповіді: спочатку приваблює неспішною та роздумливою манерою, а потім, неначе вир, стрімко й потужно засмоктує читачів у перебіг подій.

Для відображення мовлення, думок, емоцій персонажів письменник використовує різноманітні стилістичні засоби: with the brass nozzle in his fists, with this great python spitting its venomous kerosene upon the world - перифраз і персоніфікація; his eyes all orange flame - епітет і порівняння; while the flapping pigeon-winged books died on the porch- порівняння; the hidden book pound like a heart against his chest - метафора; the parlour was 
dead- епітет; the subway fled past him, cream-tile, jet-black, cream-tile, jet-black - повторення; do уои know the legend of Hercules and Antaeus - алюзія; to argue with a one-hundred-piece symphony orchestra - перефраза; the night looking at him персоніфікація; their Cheshire Cat smiles burning through the walls of the house - гіпербола; the people sleepwalking in their hallways - синекдоха. Окрім зазначених виражальних засобів, автор вживає парцельовані конструкції, які додають емоційності змісту висловлення та стають одним 3 експресивних засобів увиразнення тексту. Отже, розглянемо використання парцеляції у творі, використовуючи приклади прямої мови, опису думок та роздумів героїв роману.

На перших сторінках читач знайомиться 3 головним героєм твору пожежником Гаєм Монтегом, який живе у тоталітарній країні, а його робота полягає у спаленні книг. Він - член суспільства, яке вибрало для себе примітивні розваги, а саме Телесте, що є модернізованою версією телевізора й тривимірного проєктора, комікси та еротичні журнали: "But the public, knowing what it wanted, spinning happily, let the comic books survive. And the three-dimensional sex magazines, of course" [18, с. 55]. Автор вживає парцеляцію як показник безпосереднього живого спілкування, адже в процесі спонтанного висловлювання виключається можливість продумати усі вживані лексеми для відображення думок наперед, тому виникає потреба наголосити на важливому, розширити або уточнити інформацію, яка адресується слухачам.

Здається, що професія наклала відбиток на поведінку та мислення головного героя: він спокійний, розсудливий, підкорюється встановленим правилам, не надто емоційний зовні. Рей Бредбері створює атмосферу присутності читача, коли реципієнт поринає у зображувану автором дійсність і сприймає усе, що відбувається, «рецепторами» Монтега. Парцеляція дає змогу зрозуміти емоційні сплески головного героя: "His inner mind, reaching out to turn the corner for him, had heard the faintest whisper. Breathing?" [18, c. 3], де парцелят виражено прямим додатком у формі риторичного питання та створює ілюзію існування читача в одному просторі з героєм твору.

Знайомство головного героя з Кларисою, яка відкриває йому очі на справжній стан речей, стає першим кроком до переосмислення світу, у якому він живе. Вона зазначає: "You know, I'm not afraid of you at all."... "So many people are. Afraid of firemen, I mean" [18, с. 5]. Дівчина запинається, вагаючись чи довіритися головному персонажу, можливо, підсвідомо боїться його образити. Парцеляція спрямована на смислове поглиблення змісту базової структури та експресивне виділення тієї інформації, яку автор вважає стрижневою.
Стилістичний засіб уживається для передавання мовлення Клариси, за допомогою чого вимальовується образ дивакуватої дівчини, яка боїться залишитися незрозумілою, тому ретельно підбирає слова: "The others would walk off and leave me talking. Or threaten me" [18, c. 21]. В уривчастому ритмі, у спалахах стислих синтагм криється глибока сила переживань, а також страх героїні.

Парцелят часто спрямовує увагу на значущість висловлювання: "It's been a long time since anyone cared enough to ask. A good question" [18, c. 26]. Парцельована синтаксема, що стосується інфінітива to ask, деталізує зміст попереднього речення та спрямовує увагу не лише на предмет - question, але й на якість отриманої інформації - good. Гай - держслужбовець, або, як він називає себе, a minstrel man [18, с. 2] - міністрель вогню. Він щиро вірить у правильність ідеологічного курсу, який впроваджується у країні, але поступово настає прозріння: "I - I've been thinking. About the fire last week. About the man whose library we fixed" [18, с. 31]. Парцелятом у прикладі виступає додаток, за допомогою якого привертається увага читача до об'єкта дії. Роздуми героя стають поживним грунтом усвідомлення неминучості вибору: конфлікт із собою, або боротьба 3 тоталітарним режимом. Автор уживає паралельні парцельовані конструкції about the fire - about the man, що підсилюють ритмізацію тексту та створюють антитезу. Щодо розуміння структури синтаксичного ритму вважаємо слушною думку науковця В. Жирмунського, який зазначає, що через відсутність у прозовому творі первинних метричних закономірностей, які характерні для поезії, визначальними стають повторення сполучників, види анафори, граматико-синтаксичний паралелізм, звукові повтори, тенденція до вирівнювання числа слів, складів або наголосів [4, с. 103-114].

Кульмінацією роману стає сцена суїциду жінки, яка вирішила загинути у вогні разом із книгами, свідком чого став Гай. Читач сприймає описану подію очима Монтега, який спостерігає як "She opened the fingers of one hand slightly and in the palm of the hand was a single slender object. An ordinary kitchen match" " 18, c. 36]. У парцеляті вжито неозначений артикль an iз прикметником ordinary, що підкреслює здатність дрібної і нічого не вартої речі знищити життя людини. Останні слова базової частини a single slender object і парцельована конструкція an ordinary kitchen match вміщують однорідні члени, які сприяють ритмізації мовлення та сприяють посиленню естетичного впливу на читача. Мовознавець В. Панфілов зазначає, що саме в атрибутивній лексиці виявляється така специфічна мисленнєва діяльність людини, завдяки якій ознака, властивість, якість, що є складниками сутності того чи того предмета, 
починають мислитися окремо від нього [11, с. 123]. Аби передати загальну атмосферу тривожності та страху усіх учасників події, письменник продовжує: "The sight of it rushed the men out and down away from the house" [18, c. 36].

Змістопідсилюючу та ритмомелодійну функції виконують у тексті парцельовані конструкції, які передають думки Гая: “God, thought Montag, how true! Always at night the alarm comes. Never by day! Is it because the fire is prettier by night? More spectacle, a better show?" [18, с. 36]. Для зображення емоцій відчаю і страху персонажа Рей Бредбері використовує простий вигук-звертання God, що має паремійний контекст. Внутрішній монолог представлено у формі однієї цілісної надфразової синтаксичної єдності, що сприймається читачем як роздум персонажа. Автор підсилює емоційність висловлювання за допомогою вживання знаків оклику та питання. Такі ж прийоми використовує письменник у наступному прикладі, який представлений в особливій формі внутрішньому монолозі у наративній прозі: “how many have you taken TONIGHT! the capsules! how many will you take later and not know? and so on, every hour! or maybe not tonight, tomorrow night!" [18, с. 41]. Ця конструкція вирізняється характерним переривчастим ритмом, звучання кінцевого складу базової частини скорочується, а завершення тонального контуру продовжується на складах парцелята [12, с. 70-71]. Відбувається 3’єднання парцельованих конструкцій за допомогою сурядних сполучників та безсполучникового зв'язку. Читач відчуває розпач та розгубленість героя, що графічно представлено почерговим вживанням знаків оклику й питання. Спогади про ніч, коли його дружина ледь не померла, прийнявши велику кількість пігулок, змушує його зрозуміти, що смерть Мілдред не змусить його страждати. Натомість він поринає у спогади про зустріч 3 Кларисою, що очевидно 3 емоційно неповного речення: "And that awful flower the other day, the dandelion!” [18, c. 41]. Герой згадує розмову з дівчиною і розуміє, що дружина не стала для нього тієї спорідненою душею, якою за декілька бесід стала юнка. Важко дібрати більш влучну метафору, аби передати внутрішній стан персонажа, аніж стіна, яка виросла між Мілдред i Iacm: "Well, wasn't there a wall between him and Mildred, when you came down to it? Literally not just one, wall but, so far, three! And expensive, too!" [18, с. 41]. Автор вживає парцеляцію задля конкретизації базової частини вислову, а також передачі емоційного стану персонажа, про що свідчить знак оклику у кінці конструкцій.

Пізніше Гай Монтег дізнається від своєї дружини про трагічну смерть Клариси Маклеллан: "The same girl. McClellan. McClellan. Run over by a car. Four days ago. I'm not sure. But I think she's dead" [18, с. 44]. Для фрагментації тексту автор почергово вживає сегментацію і парцеляцію як виокремлення тематичної та рематичної структур речення. Сегментація протиставляється парцеляції щодо концентрації головної інформації: під час парцеляції семантично навантаженим є стрижневий компонент, а під час сегментації відокремлена частина, що містить тему повідомлення [7, с. 318-322]. Таке членування ритмізує прозу і створює ефект присутності читача, активізацію його відчуттів. Складається враження, що адресат не чує і не сприймає усіх слів, а інформація долинає фрагментарно, що сприймається як прояв шоку.

Заглиблюючись у внутрішній світ головного героя, бачимо постать зануреного у свій внутрішній світ інтроверта, орієнтованого на власні переживання i думки. Зображення Клариси та жінки-самогубці знову й знову виринають у пам'яті Гая: "That woman, the other night, Millie, you weren't there. You didn't see her face. And Clarisse" [18, с. 64]. Спочатку спливає образ жінки, яка здійснила самоспалення, а потім приходить згадка про дівчину, яка стала його провідником у світ, де можна захоплюватися природою, говорити про почуття й думки, просто жити. Послідовність подій передається автором за допомогою парцеляції, яка слугує засобом ілюстрації психологічного портрета героя.

Гай Монтег усвідомлює, що його світосприйняття змінюється i, бажаючи «достукатися» до дружини, запитує: "How long is it since you were really bothered? About something important, about something real?" [18, с. 49]. Емоційності висловлювання додають паралельні конструкції something important - something real, де парцелят, набуваючи комунікативної самостійності, привертає увагу читача, ніби «випадаючи» 3 рівного ритму [10, с. 143-145]. Окрім зазначеного, автор виділяє курсивом у тексті прислівник really, який i без того вживається з підсилювальним ефектом, підкреслюючи свого роду еталонну повноту повідомлюваного. Мотив здивування, який міститься у парцельованому питальному реченні, підкреслює творчу манеру письменника - словесну економність та експресивність повідомленого.

Гай Монтег повідомляє дружині про те, що він порушив закон, і вона мимоволі стає його спільницею. Автор передає розгубленість і страх героїв, що може стати відомо про хованку 3 книгами у їхньому будинку, адже в описаному суспільстві - це найважчий злочин: "Softly. They turned to stare at the door and the books toppled everywhere, everywhere in heaps" [18, c. 64]. Парцеляція використана у менш вживаній для зазначеного явища постпозиціїі. Окрім того, прикметник-парцелят 
softly і базове речення містяться у різних абзацах, що привертає ще більшу увагу читача до наступних подій.

Гай Монтег відчайдушно прагне зрозуміти сенс життя. Відчуваючи, що потребує допомоги, він звертається до Фабера - колишнього професора філології: "You're the only one I knew might help me. To see. To see” [18, с. 77]. Автор вміщуе у парцелят інфінітив у комбінації з повторенням. Очевидно, що парцеляція, вступаючи у конвергенцію 3 іншими стилістичними прийомами, посилює в такий спосіб їх прагматичний потенціал [8, с. 17]. Професор Фабер у розмові з Гаєм Монтегом, розмірковуючи про цінність і якість знань, справедливо зауважує: "Well, there we have the first thing I said we needed. Quality, texture of information" [18, с. 80]. Парцеляція вживається у сенсі конкретизації повідомлюваного, де неповна приєднувальна конструкція посилює напруженість думки і виступає засобом емоційного виділення парцельованого компонента. Читач розуміє, що головний герой повністю змінився, коли, усвідомлюючи про загрозу власному життю, повертається врятувати книги: "He remembered the books and turned back. Just on the off chance" [18, c. 115]. Не логічність задуму виконати замислене, а сподівання на таку можливість підкреслюється автором за допомогою парцельованої конструкції.

Дружина головного персонажа, примітивно мисляча мешканка мегаполісу, повністю підтримує принципи суспільства споживання. Вона не розуміє свого чоловіка, нажахана тим, що відбувається в іiі ще донедавна спокійному будинку, i тим, що Гай має намір покинути престижну професію: "You want to give up everything? After all these years of working, because, one night, some woman and her books..." [18, c. 48]. Темпоральний парцелят посідає у прикладі синтаксичну позицію детермінантного поширювача і використовується задля уточнення інформації. Емоційність повідомлюваному додають використані автором лексичні одиниці та пунктуаційні знаки.

Одним 3 персонажів, який викликає подвійні емоції, є брандмейстер Бітті - начитаний філософ-цинік, який відчайдушно прагне смерті. Йому властива неспішна і беземоційна манера мовлення зі вживанням здебільшого простих речень: "People talked too much. And they had time to think. So they ran off with the porches. And the gardens, too" [18, с. 60]. Бітті вказує на існування причинно-наслідкових зв'язків, а парцелят вміщує інформацію, яка сприймається як додаткова до основної. Складається враження, що хитрий i розумний капітан пожежної станції намагається або викрити, або наставити Гая на шлях істини, але у свідомості героя він маніяк, який отримує задоволення від опису процесу спалювання книг:
"Sit down, Montag. Watch. Delicately, like the petals of a flower. Light the first page, light the second page. Each becomes a black butterfly. Beautiful, eh?" $[18$, c. 72$]$. У парцеляції акцентується тема і відображається етапна послідовність дій.

Свою начитаність і обізнаність щодо цитат з літературних джерел брандмейстер пояснює тим, що як керівник пожежного відділення він «має орієнтуватися у визначеній темі», а ще це має бути однією з умов, щоб посісти таку посаду, про що свідчить уживання квантора most та модального дієслова have to у такому прикладі: "I'm full of bits and pieces," said Beatty. "Most fire captains have to be" [18, c. 38]. У парцельованій конструкції уточняється сенс попереднього висловлювання персонажа.

Уся жорстокість Бітті відчувається у словах, які він промовляє до Гая, коли примушує того спалити власний дім, називаючи це прибиранням: "I want you to do this job all by your lonesome, Montag. Not with kerosene and a match, but piecework, with a flamethrower" [18, с. 109]. Реченнєву єдність із базовою структурою творять парцеляти-додатки, які конкретизують зміст повідомленого в основній частині. Парцельована конструкція починається із заперечної частки not, а парцелят відображає настрій осуду та сприймається $з$ семантикою наказу. Синтаксична експресивність мови досягається завдяки сполучнику $b u t$, який вміщено у парцельованій конструкції, де на тлі протиставлення друга частина набуває нової змістової значущості.

Події набувають стрімкого розвитку, коли Гай Монтег вирішує втікати з міста. Автор використовує парцельовані конструкції і короткі номінативні речення, щоби передати напруженість ситуації під час пошуку головного персонажа: "Police Alert. Wanted: Fugitive in city. Has committed murder and crimes against the State. Name: Guy Montag. Occupation: Fireman. Last seen" [18, c. 117]. Інформація повідомляється фрагментарно, а зазначений фактичний матеріал сприймається як опис певної покрокової інструкції до виконання дій. Створюються ефект присутності читача, який полягає у відчутті реципієнтом реального спостереження за діями героїв на місці подій.

Після зустрічі з професором Фабером, зради дружини та вбивства Бітті головний герой змушений тікати. Він пливе у річці і прислуховується до спокійного биття свого серця: "He listened to his heart slow. His thoughts stopped rushing with his blood" [18, с. 134]. Монтег вперше відчуває єднання 3 природою, але спогади $з$ минулого все ще переслідують його: "The sun and time. The sun and time and burning. Burning. The river bobbled him along gently. Burning" [18, с. 134]. Під впливом емоцій висловлювання стають короткими, виникає рубаний синтаксис, який графічно позна- 
чається за допомогою крапок [22]. Явище повтору посідає особливе місце у мовній системі роману. У наведеному прикладі повторюваний герундій зазнає сильнішого акцентування, що впливає на розширення комунікативно-прагматичної бази парцелята. Водночас таке вживання реалізує функцію експресивізації мовлення і стає способом створення емоційного ефекту. Читач бачить метаморфози, які відбуваються з Гаєм, який починає відчувати себе дитям природи: "There must have been a billion leaves on the land; he waded in them, a dry river smelling of hot cloves and warm dust. And the other smells!" [18, c. 137], "He walked in the shallow tide of leaves, stumbling. And in the middle of the strangeness, a familiarity" [18, c. 138]. Парцеляція має лаконічно вивершену структуру, яка представлена додатковою приєднувальною конструкцією зі знаком оклику у першому випадку, що вказує на відчуття героя, сп'янілого від пахощів природи. Стилістичної ваги набувають парцельовані конструкції зі сполучником and, активність яких пов'язана 3 «придатністю цього сполучника відтворювати розчленований виклад, передавати його динамізм» [5, с. 303].

Нарешті Гай примикає до опозиціонерів - людей, які вирішили зберегти літературну спадщину для нащадків. У місті все ще тривають пошуки Монтега, але це не бентежить ані людей-книг, ані головного героя: "Something funny there. The chase is still running. The other way, though" [18, с. 141]. У прикладі використано обставинний парцелят способу дії, який доповнює зміст присудка. Синсемантичність парцелята підкреслює прислівник though, який контрастує з тим, що було сказано у базовій частині, підтримує структурний i граматичний зв'язок з нею та надає іронічного відтінку сказаному. Пояснюючи роль «живокниг», письменник Гренджер зазначає: "Micro-filming didn't pay off; we were always travelling, we didn't want to bury the film and come back later. Always the chance of discovery" [18, с. 145]. В основній частині вміщено прислівник частоти always, який повторюється на початку парцельованої конструкції і створює ефект експресивізації контексту, фокусує увагу на важливих деталях повідомлюваного. Парцеляти не тільки інформаційно насичені, але й стилістично значущі, оскільки концентрують інформаційно насичене тло і видозмінюють структурацію тексту, посилюючи звучання окремих частин [6]. Наприкінці роману Монтег стає свідком закінчення війни, спостерігаючи здалеку за руйнуванням міста у результаті атомного бомбардування. Він кидається долілиць на землю і «бачить» загибель рідних і знайомих, образи яких виринають у його свідомості: "Run!" he cried to Faber. To Clarisse, "Run!" To Mildred, "Run!" he cried to Faber. To Clarisse, "Run!" To Mildred, "Get out, get out of there!” [18, с. 151]. За допомогою парцеляції досягається найвищий рівень експресивності повідомлюваного. Відбувається розчленування рівноправних частин, що пояснюється необхідністю виділення змісту кожного речення. Декілька синтаксично однорідних парцелятів не тільки впливають на ритм прозового тексту, але й увиразнюють кожне попереднє речення.

Висновки й перспективи подальших розробок. Художня література є продуктивним джерелом ілюстративного матеріалу 3 огляду на насиченість мовно-стилістичними засобами, отже, на широкі можливості їх аналізу. Твір Рея Бредбері «451 градус за Фаренгейтом» було вибрано, зокрема, через відому схильність автора до включення різноманітних стилістичних прийомів.

Аналіз роману засвідчує, що парцеляція, яка використовується автором для відображення мовлення, думок, емоцій персонажів разом з іншими стилістичними засобами задля досягнення максимального впливу на читача, $є$ одним 3 елементів індивідуально-авторської манери письменника. Для дослідження було дібрано 31 текстовий фрагмент, що містить парцеляцію. Здебільшого парцельовані конструкції вжито як показник безпосереднього живого спілкування для виокремлення, розширення або уточнення важливої інформації, яка адресується читачам. Уживання стилістичного засобу у тексті виконує ритмомелодійну функцію, додає експресії кожному елементу висловлення, створює ефект присутності читача, а також увиразнює напруженість авторської думки.

У творі прослідковуються з'єднання парцельованих конструкцій за допомогою сурядних сполучників або безсполучникового зв'язку. Доведено, що самостійна форма парцельованої конструкції зумовлена функцією створення певного емоційного стилістичного ефекту на реципієнта. Окреслено основні функції, які відіграє парцеляція в ідіостилі письменника, такі як описова, емоційна, логічна, функція конкретизації сенсу повідомлюваного.

Перспективним вважаємо подальше дослідження парцеляції на матеріалі інших функціональних стилів.

\section{ЛIТЕРАТУРА}

1. Белошапкова В. Современный русский язык: Синтаксис. Москва, 1977. 248 с.

2. Боговик О. Гендерна специфіка вербальної репрезентації емоційних станів (на матеріалі роману Сідні Шелдона “Nothing lasts forever”). Закарпатські філологічні студї̈. 2020. Вип. № 14. С. 196-200. DOI: https://doi.org/10.32782/tps2663-4880/2020.14-2.36.

3. Ефремов А. Язык Н.Г. Чернышевского. Саратов, 1951. 380 с. 
4. Жирмунский В. О ритмической прозе. Русская литература. 1966. № 4. С. 103-114.

5. Завальнюк I. Синтаксичні одиниці в мові української преси початку XXI століття: функціональний і прагмалінгвістичний аспекти : монографія. Вінниця, 2009. 400 с.

6. Загнітко А. Теоретична граматика української мови: Синтаксис : монографія. Донецьк, 2001. 662 с.

7. Кондратенко Н. Дискурсивність текстової фрагментації як вияв категорії дискретності. Вісник Львівського університету. Серія «Філологія». 2004. Вип. 34. Ч. І. С. 318-322.

8. Конюхова Л. Явище парцеляції в мові сучасних засобів масової комунікації : автореф. дис. ... канд. філол. наук : спец. 10.02.01 ; Львівський державний університет ім. Івана Франка. Львів, 1999. $281 \mathrm{c}$.

9. Кузьмина Т. Парцелляция как средство достижения экспрессивности высказывания (на материале английской и американской литературы XX века). Стилистика текста. Языковые средства экспрессивности текста. Уфа, 1989. С. 23-29.

10. Мацько Л., Мацько О. Риторика : навчальний посібник. Київ, 2003. 311 с.

11. Панфилов В. Гносеологические аспекты философских проблем языкознания. Москва, 1982. 360 с.

12. Плющ Н. Парцеляція як засіб експресивного синтаксису. Українська мова і література в школі. 1981. № 1. C. 68-71.

13. Сковородников А. О соотношении понятий «парцелляция» и «присоединение» (на материале русского литературного языка). Вопросы языкознания. 1978. № 1. С. 118-129.

14. Сковородников А. О классификации парцеллированных предложений в современном русском литературном языке. Филологические науки. 1978. № 2. С. 174.

15. Чабаненко В. Стилістика експресивних засобів української мови. Запоріжжя, 2002. 351 с.

16. Языкознание: большой энциклопедический словарь. 2-е изд. / под ред. В. Ярцевой. Москва, $1998.685 \mathrm{c}$.

17. Bezrukov A., Bohovyk O. Creating Communicative Space and Textual Reality via Emotiogenic Means in Fictional Discourse. Rupkatha Journal on Interdisciplinary Studies in Humanities. 2021. Vol. 13. No. 1. P. 1-14. DOI: https://dx.doi.org/10.21659/rupkatha.v13n1.21.

18. Bradbury R. Fahrenheit 451. Simon \& Schuster Paperbacks, 2012. 159 p.

19. Crystal D., Davy D. Investigating English Style. London, 1969. 264 p.

20. Emmott C., Sanford A.J., Morrow L.I. Capturing the attention of readers? Stylistic and psychological perspectives on the use and effect of text fragmentation in narratives. Journal of Literary Semantics. 2006. № 35 (1). P. 1-30.

21. Lewis M.B. Sentence Analysis in Modern Malay. Cambridge University Press, 1969. P. 67.

22. Sechehaye A. Essai sur la structure logique de la phrase. Paris, 1950. 237 p.

23. Stubbs M. Conrad in the computer: Examples of quantitative stylistic method. Language and Literature. 2005. № 14 (1). P. 5-24.

24. Wales K. A Dictionary of Stylistics. Harlow, Longman, 2001. 429 p.

\section{REFERENCES}

1. Beloshapkova, V. (1977). Sovremennyy russkiy yazyk : Sintaksis [Modern Russian Language : Syntax]. Moskva. 248 p. [in Russian]

2. Bohovyk, O. (2020). Henderna spetsyfika verbalnoi reprezentatsii emotsiinykh staniv (na materiali romanu Sidni Sheldona "Nothing lasts forever") [Gender Differences in Verbal Representation of Emotional States in the English Fiction (Based on the Material of Sidney Sheldon's Novel "Nothing lasts forever")]. Transcarpathian philological studies, issue 14. P. 196. [in Ukrainian]

3. Efremov, A. (1951). Yazyk N. G. Chernyshevskogo [The Language of N. G. Chernyshevskiy]. Saratov. 380 p. [in Russian]

4. Zhirmunskiy, V. (1966). O ritmicheskoy proze [About Rhythmic Prose]. Russian Literature, № 4. P. 103 114. [in Russian]

5. Zavalniuk, I. (2009). Syntaksychni odynytsi v movi ukrainskoi presy pochatku XXI stolittia: funktsionalnyi i prahmalinhvistychnyi aspekty : monohrafiia [Syntactic units in the language of the Ukrainian press in the beginning of the XXI century: functional and pragma linguistic aspects: monograph]. Vinnytsia. $400 \mathrm{p}$. [in Ukrainian]

6. Zahnitko, A. (2001). Teoretychna hramatyka ukrainskoi movy: Syntaksys : Monografiia [Theoretical grammar of the Ukrainian language: Syntax: Monograph]. Donetsk. 662 p. [in Ukrainian]

7. Kondratenko, N. (2004). Dyskursyvnist tekstovoi frahmentatsii yak vyiav katehorii dyskretnosti [Discoursivity of sentence fragment as a manifestation of the category of discreteness]. Bulletin of Lviv University. Philology series, issue 34. Ch. I. P. 318-322. [in Russian] 
8. Koniukhova, L. (1999). Yavyshche partseliatsii v movi suchasnykh zasobiv masovoi komunikatsii [The phenomenon of parcelling in the language of modern media]: avtoref. dis. ... d-ra. filol. nauk : 10.02 .01 [in Ukrainian]

9. Kuzmina, T. (1989). Partsellyatsiya kak sredstvo dostizheniya ekspressivnosti vyskazyvaniya (na materiale angliyskoy i amerikanskoy literatury XX veka) [Parcellation as a Means of Achieving Expressiveness of Utterance (Based on the Material of English and American Literature of the 20th Century)]. Stylistics of the text. Language means of expressiveness of the text. Ufa. P. 23-29. [in Russian]

10. Matsko, L. and Matsko, O. (2003). Rytoryka : navch. posib [Rhetoric: a textbook]. Kyiv. 311 p. [in Ukrainian]

11. Panfilov, V. (1982). Gnoseologicheskiye aspekty filosofskikh problem yazykoznaniya [Epistemological aspects of philosophical problems of linguistics]. Moscow. 360 p. [in Russian]

12. Pliushch, N. (1981). Partseliatsiia yak zasib ekspresyvnoho syntaksysu [Parcelling as a means of expressive syntax]. Ukrainian language and literature at school. No. 1. P. 68-71. [in Ukrainian]

13. Skovorodnikov, A (1978). O sootnoshenii ponyatiy "partsellyatsiya" i "prisoyedineniye" (na materiale russkogo literaturnogo yazyka) [On the relationship between the concepts of "parcelling" and "accession" (on the material of the Russian literary language)]. Questions of linguistics. No. 1. P. 118-129. [in Russian]

14. Skovorodnikov, A. (1978). O klassifikatsii partsellirovannykh predlozheniy v sovremennom russkom literaturnom yazyke [On the classification of parceled sentences in the modern Russian literary language]. Philological sciences. No. 2. P. 174. [in Russian]

15. Chabanenko, V. (2002). Stylistyka ekspresyvnykh zasobiv ukrainskoi movy [Stylistics of expressive means of the Ukrainian language]. Zaporizhzhia. 351 p. [in Ukrainian]

16. Yazykoznaniye: Bolshoy entsiklopedicheskiy slovar(1998). [Linguistics: Big Encyclopaedical Dictionary]. 2-nd ed. / edited by V. Yartsevoy. Moscow. 685 p. [in Russian]

17. Bezrukov A., Bohovyk O. Creating Communicative Space and Textual Reality via Emotiogenic Means in Fictional Discourse. Rupkatha Journal on Interdisciplinary Studies in Humanities. 2021. Vol. 13. No. 1. P. 1-14. https://dx.doi.org/10.21659/rupkatha.v13n1.21. [in English]

18. Bradbury, R. (2012). Fahrenheit 451. Simon \&Schuster Paperbacks. 159 p. [in English]

19. Crystal, D., Davy, D. (1969). Investigating English Style. London. 264 p. [in English]

20. Emmott, C., Sanford, A. J., Morrow, L. I. (2006) Capturing the attention of readers? Stylistic and psychological perspectives on the use and effect of text fragmentation in narratives. Journal of Literary Semantics. 35(1). P. 1-30. [in English]

21. Lewis, M. (1969). Sentence Analysis in Modern Malay. Cambridge University Press. P. 67. [in English]

22. Sechehaye, A. (1950). Essai sur la structure logique de la phrase. Paris. 237 p. [in French]

23. Stubbs, M. (2005). Conrad in the computer: Examples of quantitative stylistic method. Language and Literature. 14 (1). P. 5-24 [in English]

24. Wales, K. (2001). A Dictionary of Stylistics. Harlow, Longman, 2001. 429 p. [in English] 